\title{
Spatial Distribution and Risk Assessment of Heavy Metals in Urban Road Dust From Shenyang, a Heavy Industrial City in Northeast China
}

\section{Zhengwu Cui ( $\nabla$ cuizhengwu@iga.ac.cn )}

Northeast Institute of Geography and Agroecology Chinese Academy of Sciences https://orcid.org/0000-0002-4260-1002

\section{Yang Wang}

Northeast Institute of Geography and Agroecology Chinese Academy of Sciences

Rui Yu

Northeast Institute of Geography and Agroecology Chinese Academy of Sciences

Yong Yu

Northeast Institute of Geography and Agroecology Chinese Academy of Sciences

Nana Luo

Northeast Institute of Geography and Agroecology Chinese Academy of Sciences

\section{Research Article}

Keywords: road dust, heavy metals, pollution level, source identification, health risk

Posted Date: November 12th, 2021

DOI: https://doi.org/10.21203/rs.3.rs-1051814/v1

License: (c) (1) This work is licensed under a Creative Commons Attribution 4.0 International License.

Read Full License 
Spatial distribution and risk assessment of heavy metals in urban road dust from Shenyang, a 2 heavy industrial city in Northeast China

3 Zhengwu Cui1 ${ }^{1,2}$, Yang Wang ${ }^{1}$, Rui Yu ${ }^{1}$, Yong $\mathrm{Yu}^{1}$, Nana Luo ${ }^{1,2}$

1 Key Laboratory of Wetland Ecology and Environment, Northeast Institute of Geography and Agroecology, Chinese Academy of Sciences, Changchun, China 2 University of Chinese Academy of Sciences, Beijing 100049, PR China

Corresponding author: Yang Wang. E-mail: wangyangw@iga.ac.cn industrial city in Northeast China, to study the concentration, pollution level, source, spatial distribution, and health risk of heavy metals. The average concentrations of $\mathrm{Cd}, \mathrm{Cr}, \mathrm{Cu}, \mathrm{Mn}, \mathrm{Ni}, \mathrm{Pb}$, and $\mathrm{Zn}$ were $1.802,132.1,60.33,778.3,54.80,86.73$, and $391.2 \mathrm{mg} / \mathrm{kg}$, respectively. The levels of metal pollution ranged from minimal to extremely high, with average levels in the ranked order: $\mathrm{Mn}<\mathrm{Ni}<\mathrm{Cr}<\mathrm{Cu}<$ $\mathrm{Pb}<\mathrm{Zn}<\mathrm{Cd}$, indicating that the road dust was heavily polluted by $\mathrm{Cd}, \mathrm{Zn}$, and $\mathrm{Pb}$. Source identification results demonstrated that $\mathrm{Cr}, \mathrm{Mn}$, and $\mathrm{Ni}$ had mixed sources including industrial emissions and weathering of soil, pavements, and building materials, while $\mathrm{Cu}, \mathrm{Pb}$, and $\mathrm{Zn}$ mainly originated from traffic and industrial activities, and $\mathrm{Cd}$ had a complex mixture of sources (with various anthropogenic sources). Hotspots of heavy metal pollution levels were closely correlated with local anthropogenic activities, such as industrial discharge, traffic-related exhaust emissions, and agricultural activities. Furthermore, health risk assessment revealed significant non-carcinogenic risks for children from multiple metals, and the carcinogenic risk assessment identified significant risks for children from $\mathrm{Cd}$, with ingestion being the main exposure pathway for carcinogenic and non-carcinogenic risk for adults and children. However, no health risk was observed due to dermal and inhalation exposure pathways.

Keywords: road dust, heavy metals, pollution level, source identification, health risk

\section{Introduction}

As a result of rapid global urbanization and industrialization in the last few decades, urban environmental pollution has received widespread attention (Talbi et al. 2017; Yan et al. 2018). Road dust has been found to be an important environmental media, as it can serve as a bond linking various urban environmental issues, in air, water, and soil phases ( $\mathrm{Lu}$ et al. 2017a; Lu et al. 2017b). Road dust mainly comes from the weathering of exposed soil, as well as anthropogenic activities, including the deposition of atmospheric particulates, vehicle emissions, wear of vehicle brakes and tires, abrasion of building materials and pavements, coal combustion, residential heating, and municipal activities (Li et al. 2016; Ali et al. 2017; Tang et al. 2017; Men et al. 2018b). As an environmental medium, road dust typically adsorbs high concentrations of toxic substances (e.g., heavy metals, polycyclic aromatic hydrocarbons, and polychlorinated biphenyl) (Soltani et al. 2015; Khanal et al. 2018; Anh et al. 2019). Heavy metals are considered to be one of the major environmental pollutants in urban areas, due to their characteristics of high toxicity, non-biodegradability, and bioavailability (Lanzerstorfer 2018; Men et al. 2018a). Therefore, heavy metal contamination of urban road dust and the adverse effects on both environmental and human health, have caused increasing levels of concern (Dehghani et al. 2017; Bi et al. 2018).

In recent decades, a series of studies have been conducted on the spatial distribution, source, accumulation, and health risk of heavy metals in road dust (Lu et al. 2010; Wei et al. 2015; Khademi et al. 2018). However, most of these studies have focused on developed countries or megacities (Mathur et al. 2016; Dehghani et al. 2017). In China, heavy metal contamination of road dust has been extensively 
studied in megacities, such as Beijing (Men et al. 2018b), Shanghai (Bi et al. 2018), Xi'an (Pan et al. 2017), and Nanjing (Liu et al. 2014). Urban road dust has also been found to be polluted with heavy metals in many other smaller cities in China, such as Guangzhou (Cai et al. 2013), Tianjin (Hu et al. 2016), and Hefei (Ali et al., 2017). However, these studies have largely covered the central and eastern coastal areas of China, which are not typically dominated by heavy industry and it remains unclear whether heavily industrial cities, especially in Northeast China, have a higher degree of heavy metal pollution in road dust.

Shenyang is an old industrial city in Northeast China and the administrative center of Liaoning Province. Rapid urbanization and industrialization have occurred in Shenyang under the implementation of China's Northeast Revival Strategy. According to the Shenyang statistical yearbook 2010 to 2020, the urban area in 2019 was approximately 1.5 -fold greater than in 2010 (SSB, 2020). Shenyang is a crucial industrial hub with equipment manufacturing being the major industry in the area. Large industrial companies, such as the North Heavy Industry Group Co., Ltd. (NHI), SANY Heavy Industry Co., Ltd., and AVIC Shenyang Aircraft Industry (Group) Co., Ltd., are located in this area. Although the number of industrial enterprises in Shenyang has significantly decreased in the last few years, the potentially high level of historical pollutant residues in this region should not be ignored. As of 2019, the number of motor vehicles of Shenyang had exceeded 2.5 million. Vehicle exhaust emissions and the wear of tires and brakes have resulted in the accumulation of heavy metals in urban road dust. Continuous land demand for city expansion, industrial production for economic development and the increasing volume of motor vehicles in urban areas can increase the accumulation of heavy metals in road dust. Previous studies have reported that heavy metal pollution is widely distributed in urban soil from the Tiexi industrial district of Shenyang (Li et al., 2013; Jiao et al., 2015). However, quantitative information about the accumulation, source, distribution, and health risks of heavy metals in road dust from the main urban areas remains limited. The primary aims of the present study were: 1) to investigate the heavy metals concentrations and distribution in road dust from Shenyang city; 2) to evaluate the heavy metal pollution level; 3) to identify the potential sources of different heavy metals; 4) to assess the potential health risk associated with exposure to these heavy metals, for children and adults via different exposure pathways. The results of this study provide an important multidisciplinary assessment of heavy metals in the urban environment of heavy industrial cities, providing useful guidance for the improvement and development of risk management measures in this region.

\section{Materials and methods}

\subsection{Study area}

Shenyang $\left(122^{\circ} 25^{\prime \prime}-123^{\circ} 48^{\prime} \mathrm{E}, 41^{\circ} 12^{\prime}-43^{\circ} 20^{\prime} \mathrm{N}\right)$ is the capital of Liaoning province and is one of the largest cities in Northeast China, with an urban area of $5116 \mathrm{~km}^{2}$ and an estimated population of 8.32 million. Shenyang is also one of the most important heavy industry cities in China. At the end of 2019, the number of industrial enterprises in Shenyang was 1579, among which heavy industrial enterprises accounted for 1107. Furthermore, the number of motor vehicles in the city had reached $>2.5$ million, exhibiting a 2.5 -fold increase compared to 2000 (SSB, 2020). The rapid increase in the urban population and the intensity of anthropogenic activities in Shenyang have seriously affected the environmental quality in the region and may pose a health risk to the residents of Shenyang. 


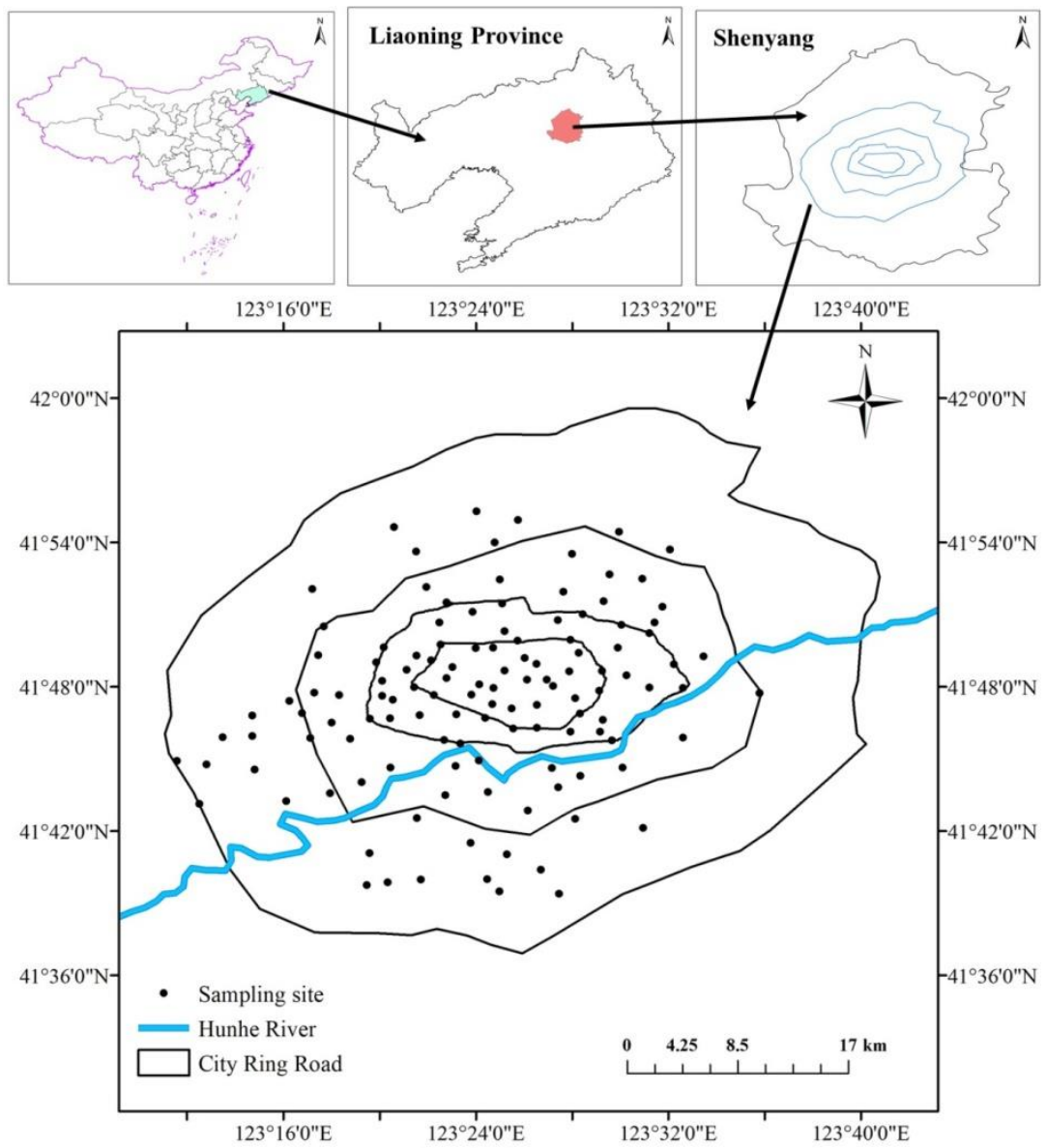

Fig. 1. Study area and the sampling locations of dust in Shenyang

\subsection{Sampling and chemical analysis}

A total of 124 dust samples were collected from the urban area of Shenyang in December 2018 after one week of continuous sunny weather (Figure. 1). The sampling sites were uniformly distributed across the main urban area of Shenyang city, with the latitude and longitude of the sampling sites recorded along with the surrounding environmental conditions. At each sampling site, four to eight sub-samples were collected from both road and pavement edges at the main street intersection and mixed thoroughly to obtain a representative bulk sample. For each sub-sample, 500-1000 g of dust was collected by slowly sweeping dust using a plastic brush and dustpan, directly transferring the dust into plastic bags, which were labeled and transported to the laboratory for analysis. Extraneous matter, such as cigarette butts, small stones, plastic waste, metal scraps, and other impurities, was manually removed from the sampling area prior to dust collection.

After the dust samples were air-dried at ambient temperature in the laboratory, they were sieved through a $53 \mu \mathrm{m}$ nylon sieve. Previous studies have reported that human exposure to dust particles smaller than $53 \mu \mathrm{m}$ in diameter can occur easily via ingestion, inhalation, or dermal absorption (Gope et al., 2018; Shi and Lu 2018). Therefore, fine particles $<53 \mu \mathrm{m}$ were selected for analysis in the present study. All dust samples were digested using the $\mathrm{HNO}_{3}-\mathrm{HClO}_{4}-\mathrm{HF}$ method (SEPA, 1997) for extraction of the metals $\mathrm{Cd}, \mathrm{Cr}, \mathrm{Cu}, \mathrm{Mn}, \mathrm{Ni}, \mathrm{Pb}$, and $\mathrm{Zn}$. The concentrations of $\mathrm{Cr}, \mathrm{Cu}, \mathrm{Mn}, \mathrm{Ni}, \mathrm{Pb}$, and $\mathrm{Zn}$ in extracts were measured by flame (air-acetylene) atomic absorption spectrophotometry (FAAS; AA-6300C, Shimadzu, Japan), while $\mathrm{Cd}$ concentrations were determined using a graphite furnace atomizer (GFA; AA-6300C, Shimadzu, Japan).

\subsection{Heavy metal pollution assessment}


The geo-accumulation index $\left(I_{g e o}\right)$, pollution index $(P I)$, and pollution load index $(P L I)$ have been widely used to assess heavy metal pollution levels (Urrutia-Goyes et al., 2018). The $I_{\text {geo }}$ and $P I$ are the most commonly applied indices used to evaluate single element pollution levels, while PLI has been widely applied for the assessment of multiple element pollution levels.

$I_{\text {geo }}$ values were calculated using Equation (1) as follows:

$I_{\text {geo }}=\log _{2}\left(\frac{C_{n}}{1.5 B_{n}}\right)$

where, $n$ indicates the heavy metal element; $C_{n}$ is the heavy metal $(n)$ concentration; and $B_{n}$ is the soil background concentration of the heavy metal, applied as $0.108 \mathrm{mg} \cdot \mathrm{kg}^{-1} \mathrm{Cd}, 57.9 \mathrm{mg} \cdot \mathrm{kg}^{-1} \mathrm{Cr}, 19.8 \mathrm{mg} \cdot \mathrm{kg}^{-}$ ${ }^{1} \mathrm{Cu}, 564 \mathrm{mg} \cdot \mathrm{kg}^{-1} \mathrm{Mn}, 25.6 \mathrm{mg} \cdot \mathrm{kg}^{-1} \mathrm{Ni}, 21.1 \mathrm{mg} \cdot \mathrm{kg}^{-1} \mathrm{~Pb}$ and $63.5 \mathrm{mg} \cdot \mathrm{kg}^{-1} \mathrm{Zn}$, respectively (CNEMC, 1990). The pollution degree was categorized as follows: $I_{\text {geo }} \leq 0$, non-polluted; $0<I_{\text {geo }} \leq 1$, light-moderate pollution; $1<I_{\text {geo }} \leq 2$, moderate pollution; $2<I_{\text {geo }} \leq 3$, moderate-heavy pollution; $3<I_{\text {geo }} \leq 4$, heavy pollution; $4<I_{\text {geo }} \leq 5$, heavy-extreme pollution; $I_{\text {geo }}>5$, extreme pollution.

The PI and PLI were calculated according to Eqs. (2) and (3) as follow (Maanan et al., 2015):

$$
P I=C_{n} / B_{n}
$$

$P L I=\sqrt[n]{P I_{1} \times P I_{2} \times P I_{3} \times \cdots \cdots \times P I_{n}}$

where, $P I$ represents the single pollution indices. The $P I$ classification was categorized as follows: $P I<1$, low contamination; 1-3, moderate contamination; $3-6$, considerable contamination; and $P I>6$, very high contamination. The $P L I$ was classified as follows: $P L I \leq 1$, low pollution; $1<P L I \leq 2$, moderate pollution; $2<P L I \leq 5$, high pollution; $P L I>5$, extremely high pollution (Gope et al., 2017).

\subsection{Health risk assessment}

The hazard quotient (HQ) and cancer risk (CR) were used to quantitatively establish the noncarcinogenic and carcinogenic risks presented by heavy metals exposure, respectively. Three exposure pathways were considered, including direct ingestion, dermal absorption, and inhalation (Gope et al., 2018). According to the Exposure Factors Handbook (USEPA, 1997), the average daily dose (ADD) $\left(\left(\mathrm{mg} \cdot \mathrm{kg}^{-1}\right) \cdot \mathrm{day}^{-1}\right)$ of an element via dust ingestion, dermal contact, and inhalation exposure pathways, can be estimated using Eqs. (4), (5), and (6) as follow:

$$
A D D_{\text {ing }}=\frac{c_{\mathrm{n}} \times \operatorname{IngR\times EF\times ED}}{B W \times A T} \times C F(4)
$$

where, IngR indicates the dust ingestion rate $\left(\mathrm{mg}^{\left.-\mathrm{day}^{-1}\right)}\right.$; EF is the exposure frequency (days $\left.\cdot \mathrm{year}^{-1}\right)$; ED is the exposure duration (years); BW refers to the average body weight $(\mathrm{kg})$; AT indicates the averaging time (days); and CF is the conversion factor $\left(1 \times 10^{-6} \mathrm{~kg} \cdot \mathrm{mg}^{-1}\right)$.

$$
A D D_{d e r}=\frac{c_{\mathrm{n}} \times S A \times A F \times A B S \times E F \times E D}{B W \times A T} \times C F(5)
$$

where, SA represents the surface area of skin in contact with the dust $\left(\mathrm{cm}^{2}\right)$; AF is the skin adherence factor for dust $\left(\mathrm{mg} \cdot\left(\mathrm{cm}^{2}\right)^{-1}\right)$; and ABS is the dermal absorption factor (chemical specific).

$$
A D D_{i n h}=\frac{c_{\mathrm{n}} \times \operatorname{Inh} R \times E F \times E D}{P E F \times B W \times A T}(6)
$$


where, InhR indicates the inhalation rate $\left(\mathrm{m}^{3} \cdot\right.$ day $\left.^{-1}\right)$; and PEF is the particle emission factor, $1.36 \times 10^{9}$ $\mathrm{m}^{3} \cdot \mathrm{kg}^{-1}$.

The potential non-carcinogenic and carcinogenic risks for individual metals were calculated using Eqs. (7), (8), and (9) (US.EPA, 1989), as follow:

$$
H Q=\frac{A D D}{R f D}
$$$$
H I=\sum H Q_{i}
$$$$
C R=\sum A D D_{i} \times S F_{i}
$$

where, RfD indicates the reference dose $(\mathrm{mg} /(\mathrm{kg} \cdot \mathrm{d}))$; and SF is the slope factor (per $(\mathrm{mg} /(\mathrm{kg} \cdot \mathrm{d}))$. The hazard index (HI) is equal to the sum of HQ, where HI values $>1$ indicate that non-carcinogenic effects may occur, while values $<1$ indicate no risk of non-carcinogenic effects (USEPA, 2001). CR values $>1 \times 10^{-4}$ indicate an unacceptable health risk, while $\mathrm{CR}$ values $<1 \times 10^{-6}$ are not considered to result in significant health effects, with risks generally regarded as tolerable in the CR value range of $10^{-6}-10^{-4}$ (Chen et al., 2015; Li et al., 2017). Detailed information on the probabilistic parameters is provided in Table S1 (supplementary materials).

\subsection{Quality assurance and quality control (QA/QC)}

Reagent blanks and analytical duplicates were used to ensure the accuracy and precision of analysis. Glassware was soaked overnight with $\mathrm{HNO}_{3}(10 \% \mathrm{v} / \mathrm{v})$ and rinsed thoroughly with deionized water prior to use. A standard reference material (GBW 07405 [GSS-5]) was obtained from the Center of National Standard Reference Material of China, for digestion and determination as part of the quality assurance (QA) protocol. The detected values of $\mathrm{Cd}, \mathrm{Cr}, \mathrm{Cu}, \mathrm{Mn}, \mathrm{Ni}, \mathrm{Pb}$, and $\mathrm{Zn}$ in the reference material were within their certified concentration ranges. The recovery rates for the seven observed metals ranged from 90\%-110\%. The limits of determination (LOD) $\left(\mathrm{mg} \cdot \mathrm{kg}^{-1}\right)$ of $\mathrm{Cd}, \mathrm{Cr}, \mathrm{Cu}, \mathrm{Mn}, \mathrm{Ni}, \mathrm{Pb}$, and $\mathrm{Zn}$ were 0.001 , $0.01,0.1,0.2,0.1,0.01$, and 0.1 , respectively.

\subsection{Statistical analysis}

Statistical analysis was performed using SPSS v.16.0 and Excel 2016. Spatial analysis was performed using GIS software to graphically and digitally present the distribution of metals. Heavy metal distribution maps were created using ArcGIS v.9.0. Principal component analysis (PCA) was carried out to cluster metals for the identification of potential sources (Pan et al., 2017). Varimax orthogonal rotation was applied to minimize the number of variables with high loading in each component and facilitate the interpretation of results. Heavy metals with the proportion of variance in $<0.5$ measurements explained by the extracted components (communality values) were excluded from PCA. In this study, all data were log-transformed prior to PCA to reduce the influence of high values.

\section{Results and discussion}

\subsection{Heavy metal concentrations}

Descriptive statistics for the analyzed heavy metal concentrations are listed in Table 1 . The background values of Liaoning topsoil (CNEMC, 1990) were applied as reference values. The mean concentrations of $\mathrm{Cd}, \mathrm{Cr}, \mathrm{Cu}, \mathrm{Mn}, \mathrm{Ni}, \mathrm{Pb}$, and $\mathrm{Zn}$ were $1.802,132.1,60.33,778.3,54.80,86.73$, and $391.2 \mathrm{mg} \cdot \mathrm{kg}^{-1}$, respectively. Compared to the soil background values, the concentrations of heavy metals in road dust all exhibited elevated concentrations. The mean concentrations of $\mathrm{Cd}, \mathrm{Zn}, \mathrm{Pb}$, and $\mathrm{Cu}$ were 
16.7-, 6.16-, 4.11-, and 3.05-fold greater than their respective background values, as well as being significantly higher than the other metals. Conversely, $\mathrm{Mn}, \mathrm{Ni}$, and $\mathrm{Cr}$ were not enriched as compared to their respective background values. Similar results have been reported in several previous studies conducted in China (Li et al., 2017), suggesting that Mn, Ni, and $\mathrm{Cr}$ might originate from natural sources, while other metals present in road dust could originate from anthropogenic activities (Liu et al., 2014). As a historically industrial city in Northeast China, different kinds of industrial activities occur in Shenyang, such as engineering and equipment manufacturing, electroplating and the production of electronics, rubber, pharmaceuticals, textiles, and electric batteries, contributing to $\mathrm{Cd}, \mathrm{Cu}, \mathrm{Pb}$, and $\mathrm{Zn}$ concentrations. As major components of petroleum and lubricants, heavy metals can be released into the atmosphere during combustion (Dao et al., 2010), with the deposition of particles from industrial and vehicle exhaust emissions leading to excessive concentrations of $\mathrm{Cd}, \mathrm{Cu}, \mathrm{Pb}$, and $\mathrm{Zn}$ in road dust (Trujillo-González et al., 2016).

Table 1 Descriptive statistics for heavy metal concentrations $\left(\mathrm{mg} \cdot \mathrm{kg}^{-1}\right)$ in road dust samples from Shenyang

\begin{tabular}{cccccccccc}
\hline & Mean & Min & Median & Max & SD & CV & Skewness & Kurtosis & $\begin{array}{c}\text { Reference } \\
\text { value }^{\mathrm{a}}\end{array}$ \\
\hline $\mathrm{Cd}$ & 1.802 & 0.010 & 1.342 & 7.440 & 1.407 & $78.07 \%$ & 1.818 & 3.245 & 0.108 \\
$\mathrm{Cr}$ & 132.1 & 41.96 & 130.9 & 263.5 & 43.90 & $33.23 \%$ & 0.163 & 0.039 & 57.90 \\
$\mathrm{Cu}$ & 60.33 & 0.110 & 58.21 & 215.9 & 33.70 & $55.85 \%$ & 1.566 & 4.657 & 19.80 \\
$\mathrm{Mn}$ & 778.3 & 412.9 & 739.0 & 5193 & 425.8 & $54.72 \%$ & 9.221 & 95.62 & 564.0 \\
$\mathrm{Ni}$ & 54.80 & 22.47 & 47.14 & 531.1 & 46.56 & $84.97 \%$ & 8.898 & 90.50 & 25.60 \\
$\mathrm{~Pb}$ & 86.73 & 23.65 & 80.56 & 411.7 & 42.19 & $48.65 \%$ & 4.126 & 28.88 & 21.10 \\
$\mathrm{Zn}$ & 391.2 & 176.2 & 375.8 & 1446 & 145.1 & $37.08 \%$ & 3.471 & 22.00 & 63.50 \\
\hline
\end{tabular}

a Background values for Shenyang topsoil. (CNEMC, 1990)

Table S2 summarizes the concentrations of heavy metals in road dust from different cities in China and worldwide. Results show that within China, the concentrations of most metals in Shenyang road dust were higher than in Beijing (Men et al., 2018b) and Xi'an (Shi and Lu, 2018), but lower than Shanghai (Bi et al., 2018), Nanjing (Li et al., 2013) and Shijiazhuang (Wan et al., 2016). Furthermore, the concentrations of most metals were lower than the levels detected in Hyderabad (India) (Mathur et al., 2016) and Toronto (Canada) (Nazzal et al., 2013). Moreover, the concentrations of heavy metals such as $\mathrm{Cu}$ and $\mathrm{Pb}$ were lower than those previously reported for Xiangyang (China), Tehran (Iran), and Kurdistan (Iraq) (Shi et al., 2013; Dehghani et al., 2017; Amjadian et al., 2018). The concentrations of $\mathrm{Cd}, \mathrm{Cr}$, Mn, and $\mathrm{Zn}$ were higher than those detected in the road dust from most cities, while Ni concentrations were not significantly different from those reported for other cities. In general, the metal concentrations in road dust in the present study were relatively moderate compared with the concentrations reported for other cities.

\subsection{Pollution indices}

To further characterize the heavy metal pollution level in dust, Igeo, PI, and PLI values were calculated (Fig. 2 and Table S3). The $\mathrm{I}_{\text {geo }}$ values ranged from -4.22 to 5.22 for $\mathrm{Cd}$ (mean 3.06), -1.05 to 1.60 for $\mathrm{Cr}$ (mean 0.51 ), -8.04 to 2.86 for $\mathrm{Cu}$ (mean 0.75), -1.04 to 2.62 for $\mathrm{Mn}$ (mean -0.19 ), -0.77 to 3.79 for $\mathrm{Ni}$ (mean 0.36), -0.42 to 3.70 for $\mathrm{Pb}$ (mean 1.33) and 0.89 to 3.92 for $\mathrm{Zn}$ (mean 1.97). The mean $\mathrm{I}_{\text {geo }}$ values were ranked in the decreasing order of $\mathrm{Cd}>\mathrm{Zn}>\mathrm{Pb}>\mathrm{Cu}>\mathrm{Cr}>\mathrm{Ni}>\mathrm{Mn}$ (Fig. 2a). The mean $\mathrm{I}_{\text {geo }}$ for $\mathrm{Cd}$ pollution indicated heavily polluted conditions, while $\mathrm{Zn}$ and $\mathrm{Pb}$ pollution was moderate. Meanwhile, the mean $\mathrm{I}_{\text {geo }}$ values obtained for $\mathrm{Cu}, \mathrm{Cr}$, and $\mathrm{Ni}$ indicated light to moderate pollution 
conditions, while urban dust exhibited almost no Mn pollution. Table S3 presents the heavy metal contamination distribution characteristics. For $\mathrm{Cd}, \mathrm{Zn}$, and $\mathrm{Pb}$, about $96.0 \%, 99.2 \%$, and 77.4\% of all dust samples, respectively, exhibited moderate pollution levels or greater. Therefore, $\mathrm{Cd}, \mathrm{Zn}$, and $\mathrm{Pb}$ were the primary contributors to contamination in urban road dust from Shenyang.

PI values calculated according to the local soil background values varied significantly for different metals (Fig. 2b and Table S3). The mean PI values for all metals were ranked in the descending order of $\mathrm{Cd}>\mathrm{Zn}>\mathrm{Pb}>\mathrm{Cu}>\mathrm{Cr}>\mathrm{Ni}>\mathrm{Mn}$. The PI values for $\mathrm{Cd}, \mathrm{Pb}$, and $\mathrm{Zn}$ ranged from 0.08 to $68.9,1.12$ to 19.5, and 2.77 to 22.8 , respectively, with mean values of $16.7,4.11$, and 6.16. For $\mathrm{Cd}, \mathrm{Pb}$, and $\mathrm{Zn}, 96.0 \%$, $77.4 \%$ and $99.2 \%$ of all samples contained considerable pollution levels or greater (PI $>3$ ), indicating that the road dust of Shenyang was seriously contaminated with $\mathrm{Cd}, \mathrm{Pb}$, and $\mathrm{Zn}$. Igeo and PI results indicated that $\mathrm{Cd}, \mathrm{Pb}$, and $\mathrm{Zn}$ were the main contaminants in the urban road dust of Shenyang, which may originate from traffic-related exhaust sources (tire, brake and asphalt wear and abrasion) and industrial emissions (Men et al. 2018b; Gope et al. 2018). These results also indicate that $\mathrm{I}_{\text {geo }}$ and PI can feasibly be used to evaluate heavy metal pollution levels in road dust.

As shown in Fig. 2c and Table S3, the PLI values of all dust samples ranged from 1.25 to 5.73, with an average of 3.33, indicating a high pollution level in the urban road dust of Shenyang. There were only four samples (3.23\% of all samples) with PLI values below 2, while 94.4\% (117 samples) had PLI values between 2 and 5, and 2.42\% (3 samples) had PLI values above 5. Overall, these findings suggested that the study area exhibited almost entirely high pollution levels with the urban road dust of Shenyang being seriously polluted by anthropogenic activities.
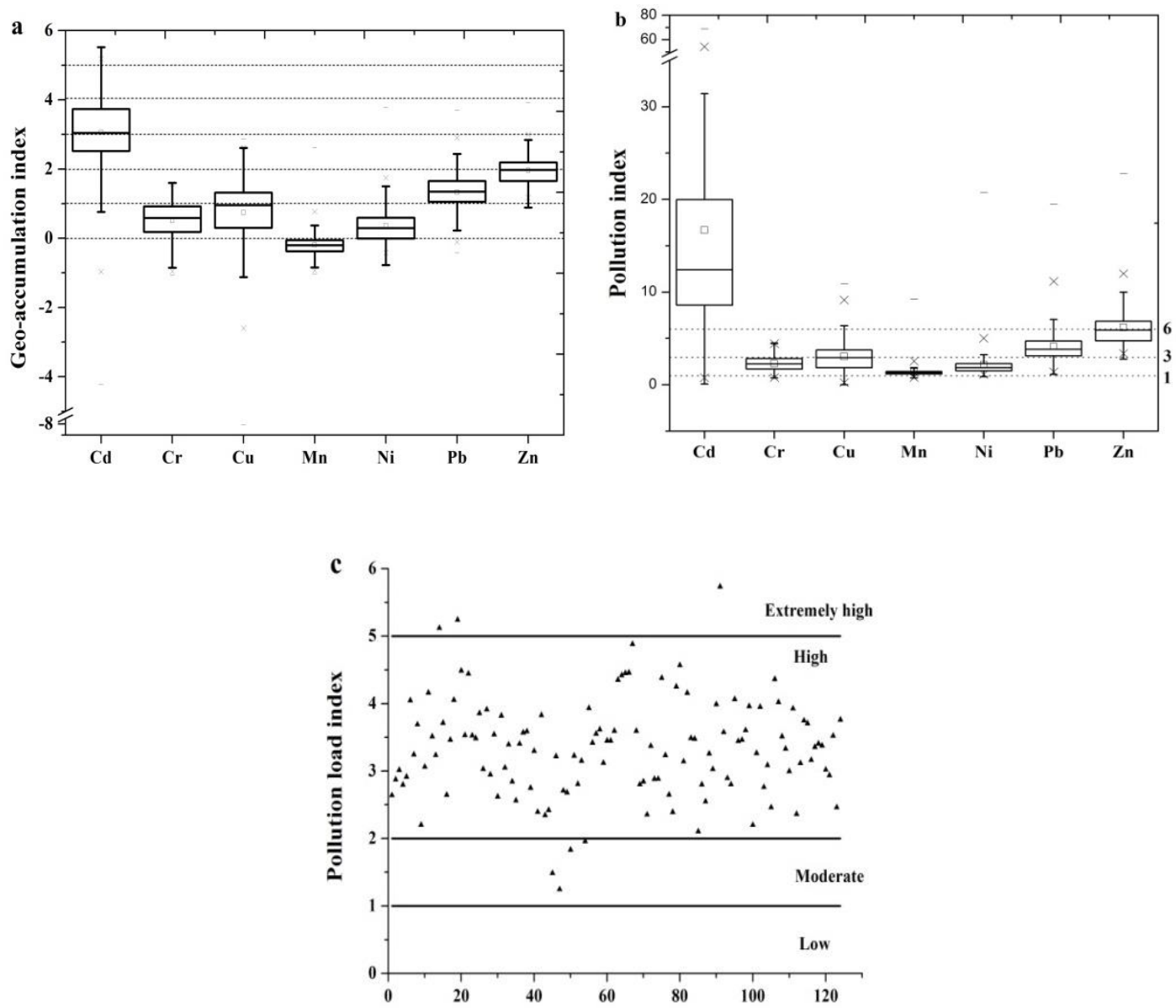

Fig. 2. a) Geo-accumulation index ( $\left.\mathrm{I}_{\mathrm{geo}}\right)$; b) Pollution index (PI); and c) Pollution load index (PLI) for 
heavy metals in urban road dust from Shenyang (China).

\subsection{Source identification}

Correlations between heavy metals can reflect their sources and pathways (Yang et al., 2011; Lu et al., 2017a). Pearson correlation analysis results are shown in Table 2. Except for an extremely negative correlation with Ni $(\mathrm{p}<0.01)$, Cd had no significant correlations with any other heavy metals. Positive correlations $(\mathrm{P}<0.01)$ were found between several element pairs: $\mathrm{Cr}-\mathrm{Mn}(\mathrm{r}=0.378), \mathrm{Cr}-\mathrm{Ni}(\mathrm{r}=0.369)$, $\mathrm{Cu}-\mathrm{Ni}(\mathrm{r}=0.254), \mathrm{Cu}-\mathrm{Pb}(\mathrm{r}=0.272), \mathrm{Cu}-\mathrm{Zn}(\mathrm{r}=0.488), \mathrm{Zn}-\mathrm{Mn}(\mathrm{r}=0.277), \mathrm{Zn}-\mathrm{Ni}(\mathrm{r}=0.254)$, and $\mathrm{Zn}-\mathrm{Pb}$ $(\mathrm{r}=0.334)$. Three element pairs, $\mathrm{Cr}-\mathrm{Cu}(\mathrm{r}=0.189), \mathrm{Cr}-\mathrm{Zn}(\mathrm{r}=0.205)$ and $\mathrm{Cu}-\mathrm{Mn}(\mathrm{r}=0.214)$, exhibited a significantly positive correlation $(\mathrm{P}<0.05)$. Similarly, Gope et al. (2018) identified a positive correlation between $\mathrm{Cr}-\mathrm{Mn}, \mathrm{Cr}-\mathrm{Ni}, \mathrm{Cu}-\mathrm{Pb}, \mathrm{Cu}-\mathrm{Zn}$, and $\mathrm{Pb}-\mathrm{Zn}$ in the street dust of Durgapur, India, while Li et al., (2013) reported a positive correlation between $\mathrm{Cr}-\mathrm{Mn}, \mathrm{Cu}-\mathrm{Pb}, \mathrm{Cu}-\mathrm{Zn}, \mathrm{Zn}-\mathrm{Mn}$, and $\mathrm{Pb}-\mathrm{Zn}$ in urban soil from Shenyang, China. According to previous studies, $\mathrm{Cr}, \mathrm{Cu}, \mathrm{Mn}$, and $\mathrm{Zn}$ are commonly positively correlated, indicating that industrial emissions might be the source, such as steel and alloy processing and thermal power plants (Mousavian et al., 2017; Dietrich et al., 2018). Similarly, a positive correlation was found between $\mathrm{Pb}$ and $\mathrm{Zn}$, which might be related to traffic activities (Gope et al., 2018). Cr and Ni are commonly found to be highly correlated in road dust, potentially deriving from a mixture of natural (weathering of soils and pavement) (Yan et al., 2018) and anthropogenic (abrasion of alloys used invehicle components and thermal power plants) sources (Chen et al., 2014; Usmani and Kumar 2017). Therefore, the sources of heavy metals in road dust are complex and inconclusive, with the results of correlation analysis not able to identify a dominant source. Therefore, other multivariate statistical analyses were carried out to further explore the relationship between these heavy metals and their sources. Table 2 Pearson's correlations matrix for metal concentrations in urban road dust from Shenyang (China).

\begin{tabular}{cccccccc}
\hline & $\mathrm{Cd}$ & $\mathrm{Cr}$ & $\mathrm{Cu}$ & $\mathrm{Mn}$ & $\mathrm{Ni}$ & $\mathrm{Pb}$ & $\mathrm{Zn}$ \\
\hline $\mathrm{Cd}$ & 1 & -0.14 & -0.085 & 0.055 & $\mathbf{- 0 . 4 1 0 * *}$ & -0.064 & -0.098 \\
$\mathrm{Cr}$ & & 1 & $\mathbf{0 . 1 8 9 *}$ & $\mathbf{0 . 3 7 8 * *}$ & $\mathbf{0 . 3 6 9 * *}$ & 0.09 & $\mathbf{0 . 2 0 5 *}$ \\
$\mathrm{Cu}$ & & 1 & $\mathbf{0 . 2 1 4 *}$ & $\mathbf{0 . 2 5 4 * *}$ & $\mathbf{0 . 2 7 2 * *}$ & $\mathbf{0 . 4 8 8 * *}$ \\
$\mathrm{Mn}$ & & & 1 & 0.071 & -0.002 & $\mathbf{0 . 2 7 7 * *}$ \\
$\mathrm{Ni}$ & & & & 1 & 0.137 & $\mathbf{0 . 2 5 4 * *}$ \\
$\mathrm{Pb}$ & & & & & 1 & $\mathbf{0 . 3 3 4 *}$ \\
$\mathrm{Zn}$ & & & & & & & 1 \\
\hline
\end{tabular}

*. Correlation significant at the 0.05 level (2-tailed).

**. Correlation significant at the 0.01 level (2-tailed).

Principal component analysis (PCA) was used to study the established correlations, with the aim of providing information on the distribution and sources of heavy metal pollutants. The PCA results indicate that there were three components with eigenvalues $>1$, which explained $67.33 \%$ of the total variance (Table 3). PC1 was loaded primarily with $\mathrm{Cu}, \mathrm{Pb}$, and $\mathrm{Zn}$, accounting for $24.81 \%$ of the total variance. $\mathrm{Cu}, \mathrm{Pb}$, and $\mathrm{Zn}$ are mainly associated with vehicle exhaust emissions (Pan et al., 2017; Gope et al., 2018). The $\mathrm{Cu}$ content of road dust may come from engine and brake wear, as well as mechanical abrasion of vehicle parts, while $\mathrm{Zn}$ mainly originates from lubricating oil and attrition of automobile tires (Dehghani et al, 2017). Historically, $\mathrm{Pb}$ has been an important gasoline additive and although China banned the addition of $\mathrm{Pb}$ to gasoline since the early 2000's, $\mathrm{Pb}$ has a long half-life and a low leaching rate, leading to its accumulation in urban environments over time (Yang et al., 2011). It has also been reported that 
$\mathrm{Cu}, \mathrm{Pb}$, and $\mathrm{Zn}$ are related to industrial activities as they can be released during metal processing and smelting (Dietrich et al., 2018). Therefore, PC1 was mainly related to traffic and industrial activities.

PC2 explained $21.43 \%$ of the total variance and was heavily loaded with Cd and Ni. As shown in Table 2, Cd (-0.841) exhibited an inverse loading trend compared to $\mathrm{Ni}$ (0.787), indicating distinct sources for $\mathrm{Cd}$ and $\mathrm{Ni}$. Based on the metal concentrations and pollution indices, Ni originated from mixed natural and anthropogenic sources, with emissions from steel and alloy industries, corrosion of vehicle body parts and abrasion of asphalt pavements being the main sources for Ni accumulation (Dehghani et al, 2017; Li et al., 2017; Lu et al, 2017a; Gope et al, 2018). In contrast, the sources of Cd were more complex. Cd is widely used to shelter alloy surfaces and building materials, as well as in electroplating, and the production of batteries, plastics and fertilizers (Yıldırım and Tokalıoğlu., 2016). In recent years, there have been a large number of urban constructions in Shenyang, including commercial and residential buildings, a subway, and road widening schemes. As a consequence, traffic sources (lubricating oil and tire wear) (Men et al., 2018b), industrial sources (thermal power plants and steel) (Gope et al., 2018), building materials (commercial and residential buildings, road and subway) (Wei et al., 2010) and agricultural sources (fertilizers and pesticides) (Li et al., 2017), are all potential sources of Cd in the road dust of Shenyang.

The third principal component (PC3) explained $21.10 \%$ of the total variance and was heavily loaded with $\mathrm{Cr}$ and $\mathrm{Mn}$. According to the results of statistical analysis and previous studies, $\mathrm{Cr}$ and Mn are likely to originate from mixed sources, mostly from the weathering of parent materials, with a smaller contribution from industrial emissions. Fly ash produced by burning coal might be a main factor causing the accumulation of $\mathrm{Cr}$ and $\mathrm{Mn}$ in road dust (Raja et al., 2014; Wang et al., 2016). Moreover, emissions from the smelting industry present another anthropogenic source for these two metals (Men et al., 2018b). Table 3 Rotated principal component matrix for heavy metals in the urban road dust of Shenyang (PCA loadings $>0.5$ are shown in bold).

\begin{tabular}{lccc}
\hline \multirow{2}{*}{ Element } & \multicolumn{3}{c}{ Component } \\
\cline { 2 - 4 } & \multicolumn{2}{c}{$\mathrm{PC} 1$} & $\mathrm{PC} 1$ \\
\hline $\mathrm{Cd}$ & -0.014 & $\mathrm{Cd}$ & -0.014 \\
$\mathrm{Cr}$ & 0.065 & $\mathrm{Cr}$ & 0.065 \\
$\mathrm{Cu}$ & $\mathbf{0 . 7 3 0}$ & $\mathrm{Cu}$ & $\mathbf{0 . 7 3 0}$ \\
$\mathrm{Mn}$ & 0.131 & $\mathrm{Mn}$ & 0.131 \\
$\mathrm{Ni}$ & 0.202 & $\mathrm{Ni}$ & 0.202 \\
$\mathrm{~Pb}$ & $\mathbf{0 . 7 4 6}$ & $\mathrm{Pb}$ & $\mathbf{0 . 7 4 6}$ \\
$\mathrm{Zn}$ & $\mathbf{0 . 7 6 5}$ & $\mathrm{Zn}$ & $\mathbf{0 . 7 6 5}$ \\
Eigenvalue & 2.294 & Eigenvalue & 2.294 \\
Total variance $(\%)$ & 24.81 & Total variance $(\%)$ & 24.81 \\
$\mathrm{Cumulative}$ variance $(\%)$ & 24.81 & Cumulative variance $(\%)$ & 24.81 \\
\hline
\end{tabular}

3.4 Spatial distribution

Spatial distribution analysis is a useful method for determining the hotspots of elevated heavy metal concentrations and to identify the potential sources. The estimated maps of $\mathrm{Cd}, \mathrm{Cr}, \mathrm{Cu}, \mathrm{Mn}, \mathrm{Ni}, \mathrm{Pb}$, and $\mathrm{Zn}$ pollution are presented in Fig. 3, showing that the concentrations of heavy metals in road dust exhibited a high level of spatial variation. The Cd hotpots had relatively high spatial variability, indicating 
that the sources of $\mathrm{Cd}$ were complex, mainly concentrated in industrial, urban, and suburban areas. Industrial emissions (thermal power plants, Fe and steel industries) (Verma et al., 2015; Mousavian et al., 2017), vehicular emission (brake wear, tire wear, and engine oil) (Dehghani et al., 2017), and the application of pesticides (Cui et al., 2018), may be the major sources for Cd accumulated in road dust. Among these metals, $\mathrm{Cr}, \mathrm{Cu}, \mathrm{Mn}$, and $\mathrm{Zn}$ exhibited similar spatial distribution patterns, indicating that these metals may have the same sources. The hotspots of $\mathrm{Cr}, \mathrm{Cu}, \mathrm{Mn}$, and $\mathrm{Zn}$ were found to be located in the Tiexi industrial district, which might be related to several industrial emission sources. As essential metals in various metal processing activities, $\mathrm{Cr}, \mathrm{Cu}, \mathrm{Mn}$, and $\mathrm{Zn}$ are widely used to control redox reactions and improve the strength and hardness of steel and alloys (Gong et al., 2014; Dietrich et al., 2018). Historically, the Tiexi industrial district has been one of the largest heavy industry zones in China, with the smelting industry in this region being the backbone of China's metallurgical industry (Li et al., 2013). As of the end of 2019, there were more than 100 large scale Fe and steel smelting enterprises in Shenyang (SSB, 2020), which may be a main reason for the accumulation of $\mathrm{Cr}, \mathrm{Cu}, \mathrm{Mn}$, and $\mathrm{Zn}$ in road dust in this region. Furthermore, some hotspots identified pollution point sources, which might be related to the steel and non-ferrous metal markets in the north of the study area and the cement plants in the east (Ogunkunle and Fatoba, 2014). The spatial distribution of Ni pollution was relatively even, with the only hotspot area located in the mid-east of the city, which might be associated with engine manufacturers located nearby. Ni-based alloys are widely used in modern engines due to their outstanding performance in harsh environments, accounting for 40-60\% of the total weight of engine materials (Ding et al., 2018). Therefore, the spatial distribution of $\mathrm{Ni}$ might be influenced by soil parent materials and industrial emissions. The Pb hotspot areas were found to be mainly located within the second ring road area, which is the political, economic, and cultural center of Shenyang with a high traffic volume, indicating that vehicular-related activities significantly contribute to $\mathrm{Pb}$ accumulation in road dust. In China, although petrol with $\mathrm{Pb}$ additives was banned two decades ago, $\mathrm{Pb}$ concentrations in urban soil still reflect the significant degree of historical $\mathrm{Pb}$ contamination and the long half-life of $\mathrm{Pb}$ (Yang et al., 2011). Moreover, $\mathrm{Pb}$ can accumulate in urban road dust from soil via resuspension (Chen et al., 2014). However, vehicular sources (i.e., vehicles using leaded petrol) are still the main sources of atmospheric $\mathrm{Pb}$, leading to the increase in $\mathrm{Pb}$ concentrations in urban road dust.

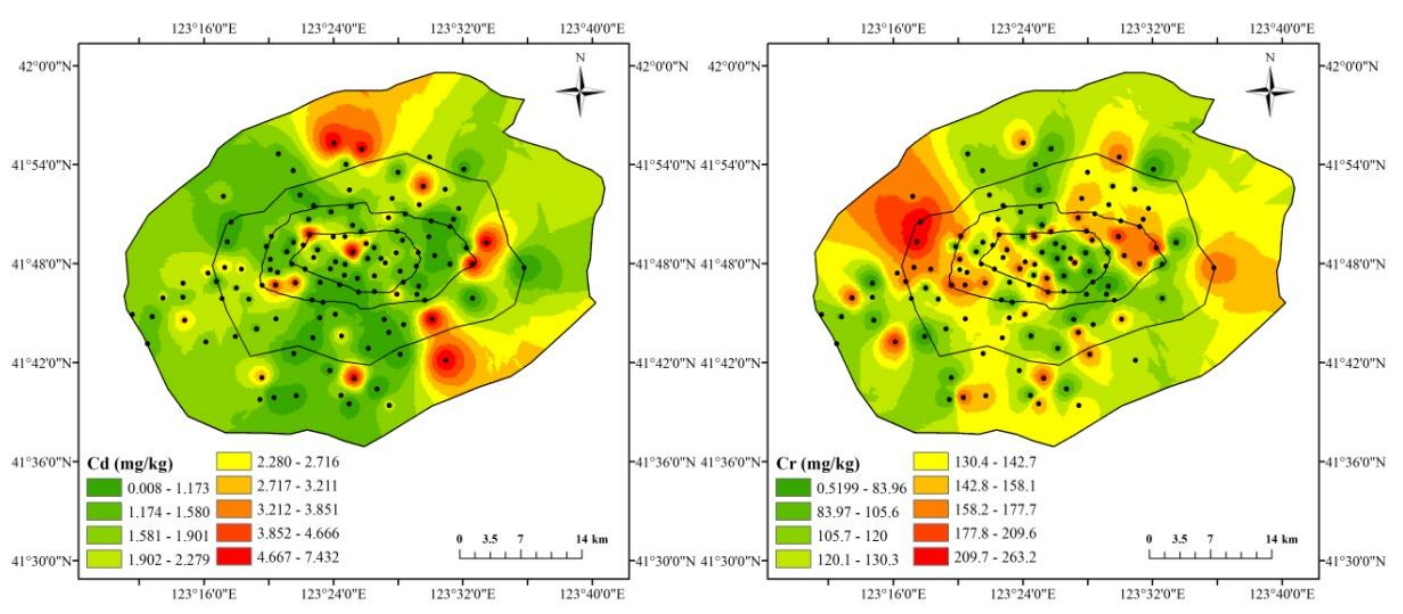



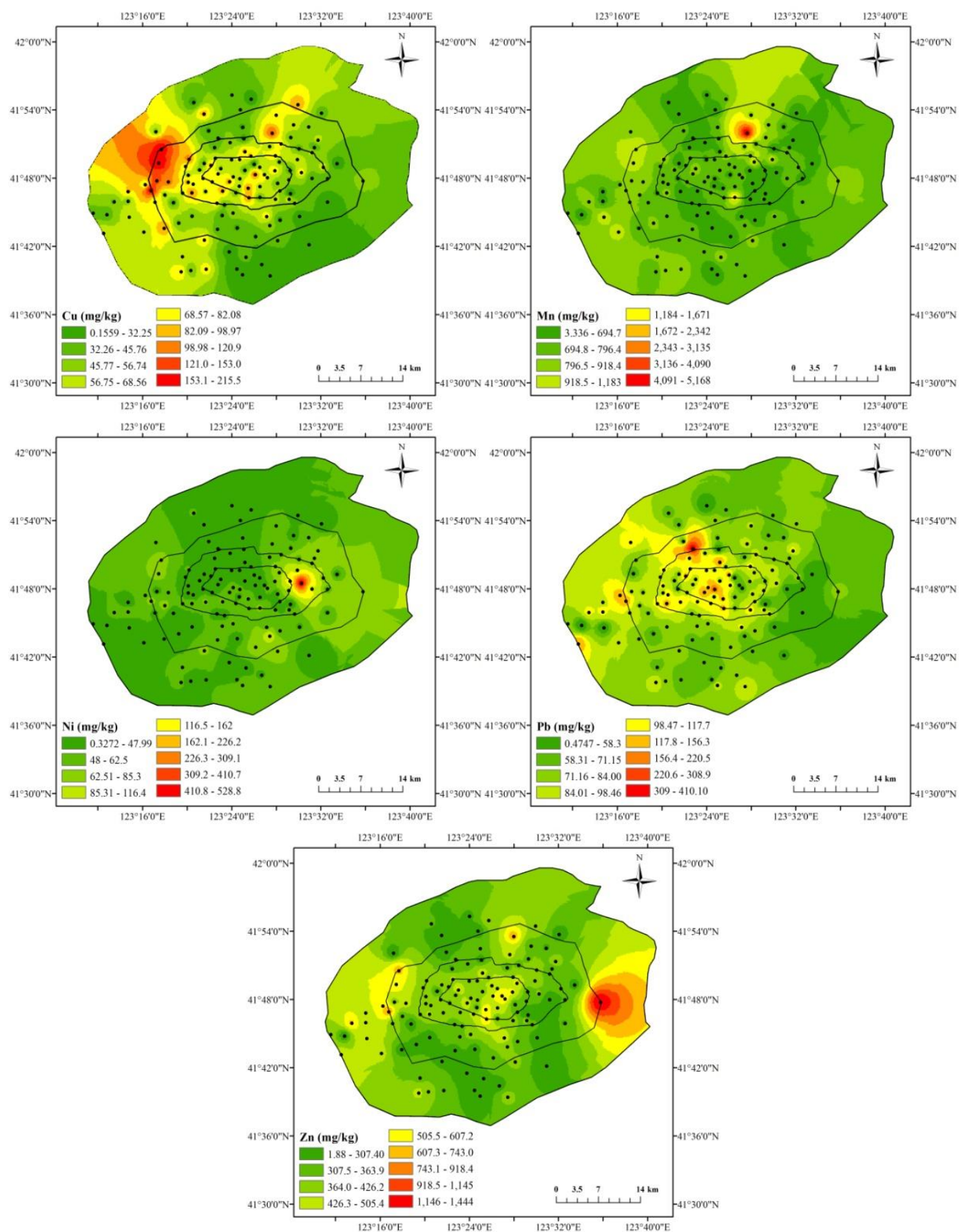

Fig. 3. Spatial distribution of heavy metal concentrations in urban road dust from Shenyang.

\subsection{Health risk assessment}

The non-carcinogenic and carcinogenic risks presented by heavy metals in road dust are shown in Table S4. For non-carcinogenic effects, the health risks for children were higher than for adults. Children are more susceptible to the effects of heavy metals, due to children's behavioral and physiological characteristics, including hand-to-mouth activities and higher breathing rate per unit body weight (Liu et al., 2018). The total HI values of multiple metals for adults and children were 0.24 and 1.64, respectively, indicating that children could suffer from non-carcinogenic effects of multiple heavy metal exposure. The HQ values for children were $<1$ for all the assessed metals, which were ranked in the descending order of $\mathrm{Cr}>\mathrm{Pb}>\mathrm{Mn}>\mathrm{Cu}>\mathrm{Ni}>\mathrm{Cd}>\mathrm{Zn}$. Although the children's HQ value for $\mathrm{Cr}(0.68)$ was below the safety threshold, if children are exposed to a sufficiently large dose over a long term period, it may 
cause neurological and developmental disorders. Therefore, exposure of $\mathrm{Cr}$ in urban dust in Shenyang could pose a potential threat to children's health. The contribution from the ingestion pathway was the highest (88.4\% for children and $66.8 \%$ for adults), followed by dermal contact and inhalation, which is consistent with the reported results of earlier studies (Chabukdhara and Nema, 2013; Tang et al., 2017).

Due to the lack of corresponding RfD or SF values, only $\mathrm{Cd}, \mathrm{Cr}$, and Ni were evaluated in terms of their carcinogenic risk. Cd exposure was evaluated for all three pathways, while $\mathrm{Cr}$ and $\mathrm{Ni}$ were only evaluated for carcinogenic health risks via the inhalation pathway. CR values for multiple metal exposure for adults and children were $2.17 \times 10^{-5}$ and $1.65 \times 10^{-4}$, respectively (Table S4). The carcinogenic risk for children was higher than the maximum tolerable value $\left(1 \times 10^{-4}\right)$, while the carcinogenic risk for adults was within the acceptable range $\left(1 \times 10^{-6}-1 \times 10^{-4}\right)$. For adults and children, the $\mathrm{CR}$ values for $\mathrm{Ni}$ were below the negligible risk level of $1 \times 10^{-6}$, indicating no significant effect on health. The carcinogenic risk levels for $\mathrm{Cr}$ for adults and children and $\mathrm{Cd}$ for adults were within the acceptable limits, while the $\mathrm{CR}$ values for $\mathrm{Cd}$ for children were 1.59-fold higher than the $\mathrm{CR}$ threshold. The ingestion pathway accounted for $93.1 \%$ and $96.4 \%$ of the total CR for adults and children, respectively, which was much higher than the other two pathways, indicating that ingestion was the main CR exposure pathway for both adults and children. Therefore, the non-carcinogenic and carcinogenic risks to children in the study area were higher than the risk to adults, highlighting the need for more research attention in this field and the development of effective mitigation measures.

\section{Conclusions}

The present study determined the concentrations, pollution level, spatial distribution, and health risks of $\mathrm{Cd}, \mathrm{Cr}, \mathrm{Cu}, \mathrm{Mn}, \mathrm{Ni}, \mathrm{Pb}$, and $\mathrm{Zn}$ in urban road dust from Shenyang, Northeast China. The mean concentrations of $\mathrm{Cd}, \mathrm{Cr}, \mathrm{Cu}, \mathrm{Mn}, \mathrm{Ni}, \mathrm{Pb}$, and $\mathrm{Zn}$ in road dust samples were significantly higher than the corresponding soil background values, with $\mathrm{Cd}, \mathrm{Pb}$, and $\mathrm{Zn}$ being the main polluting metals as indicated by $I_{\text {geo }}$ and PI values ranging from moderate to heavy/high contamination levels. Based on PLI values, almost all the study areas were highly polluted. PCA results showed that $\mathrm{Cu}, \mathrm{Pb}$, and $\mathrm{Zn}$ mainly originated from traffic and industrial sources; $\mathrm{Cr}, \mathrm{Mn}$, and $\mathrm{Ni}$ had mixed industrial and natural sources; and $\mathrm{Cd}$ had a complex source profile related to industrial emissions, vehicular exhaust emissions, building materials, and agricultural activities. GIS mapping further revealed the locations of heavily polluted hotspots for the seven assessed metals. The hotspots of $\mathrm{Cr}, \mathrm{Cu}, \mathrm{Mn}$, and $\mathrm{Zn}$ exhibited similar distribution patterns, which were mainly distributed in the Tiexi district and associated with industrial activities. The spatial distributions of $\mathrm{Cd}, \mathrm{Ni}$, and $\mathrm{Pb}$ were different from the other metals. Industrial emissions, vehicular emissions, and agricultural activities may be the factors affecting the distribution of Cd hotspots, high traffic density and historical leaded petrol residues were the main factors influencing $\mathrm{Pb}$ hotspots, while the spatial distribution of $\mathrm{Ni}$ was relatively homogeneous, with only one hotspot area potentially associated with manufacturing emissions. Although exposure to individual metals in urban road dust exhibited a relatively low health risk, the non-carcinogenic risks associated with exposure multiple metals in children exceeded the acceptable level, indicating that children might experience noncarcinogenic effects. The carcinogenic risks of exposure to $\mathrm{Cr}$ by both children and adults and $\mathrm{Cd}$ by adults were within the acceptable range, while exposure to $\mathrm{Cd}$ by children presented an unacceptable risk. Finally, ingestion was found to be the primary exposure pathway for non-carcinogenic and carcinogenic risks for adults and children.

\section{Acknowledgments}


This research was funded by the Strategic Priority Research Program of the Chinese Academy of Sciences, Grant No. XDA23070502; Natural Science Foundation of Jilin Province, Grant No.20190103161JH.

The authors would like to thank all the laboratory persons as well as colleagues for providing their help during sampling and analysis. The authors appreciate the reviewers and editors for their assistance in the development and improvement of this paper.

\section{Reference}

Ali M U, Liu G, Yousaf B, Abbas Q, Ullah H, Munir M, Fu B (2017). Pollution characteristics and human health risks of potentially (eco)toxic elements (PTEs) in road dust from metropolitan area of Hefei, China. Chemosphere, 181:111-121. https://doi.org/10.1016/j.chemosphere.2017.04.061

Amjadian K, Pirouei M, Rastegari Mehr M, Shakeri A, Khurshid Rasool S, Ibrahim Haji D (2018). Contamination, health risk, mineralogical and morphological status of street dusts- case study: Erbil metropolis, Kurdistan Region-Iraq. Environmental pollution (Barking, Essex : 1987), 243(Pt B):1568-1578. https://doi.org/10.1016/j.envpol.2018.09.116

Anh H Q, Watanabe I, Tomioka K, Minh T B, Takahashi S (2019). Characterization of 209 polychlorinated biphenyls in street dust from northern Vietnam: Contamination status, potential sources, and risk assessment. The Science of the total environment, 652:345-355. https://doi.org/10.1016/j.scitotenv.2018.10.240

Bi C, Zhou Y, Chen Z, Jia J, Bao X (2018). Heavy metals and lead isotopes in soils, road dust and leafy vegetables and health risks via vegetable consumption in the industrial areas of Shanghai, China. Science of the Total Environment 619-620:1349-1357. https://doi.org/10.1016/j.scitotenv.2017.11.177.

Cai Q, Mo C, Li H, Lü H, Zeng Q, Li Y, Wu X (2013). Heavy metal contamination of urban soils and dusts in Guangzhou, South China. Environmental Monitoring and Assessment 185(2):10951106. https://doi.org/10.1007/s10661-012-2617-x.

Chabukdhara M, Nema AK (2013). Heavy metals assessment in urban soil around industrial clusters in Ghaziabad, India: probabilistic health risk approach. Ecotoxicology and Environmental Safety 87(1):57-64. https://doi.org/10.1016/j.ecoenv.2012.08.032.

Chen H, Teng Y, Lu S, Wang Y, Wang J (2015). Contamination features and health risk of soil heavy metals in China. Science of The Total Environment 512-513:143-153. https://doi.org/10.1016/j.scitotenv.2015.01.025

Chen H., Lu X, Li LY, Gao T, Chang Y (2014). Metal contamination in campus dust of Xi'An, China: a study based on multivariate statistics and spatial distribution. Science of the Total Environment 484:27-35. https://doi.org/10.1016/j.scitotenv.2014.03.026.

CNEMC (Chinese National Environmental Monitoring Center) (1990). The Soil Background Value in China. China Environmental Science Press, Beijing. (in Chinese)

Cui Z, Wang Y, Zhao N, Yu R, Xu G, Yu Y (2018). Spatial distribution and risk assessment of heavy metals in paddy soils of Yongshuyu irrigation area from songhua river basin, Northeast China. Chinese Geographical Science 28(5):797-809. https://doi.org/10.1007/s11769-018-0991-1.

Dao L, Morrison L, Zhang C (2010). Spatial variation of urban soil geochemistry in a roadside sports ground in Galway, Ireland. Science of Total Environment 408:1076-1084. https://doi.org/10.1016/j.scitotenv.2009.11.022.

Dehghani S, Moore F, Keshavarzi B, Hale BA (2017). Health risk implications of potentially toxic metals 
in street dust and surface soil of Tehran, Iran. Ecotoxicology and Environmental Safety 136:92103. https://doi.org/10.1016/j.ecoenv.2016.10.037.

Dietrich M, Huling J, Krekeler MPS (2018). Metal pollution investigation of Goldman Park, Middletown Ohio: Evidence for steel and coal pollution in a high child use setting. Science of The Total Environment 618:1350-1362. https://doi.org/10.1016/j.scitotenv.2017.09.246.

Ding W, Miao Q, Li B, Xu J (2018). Review on Grinding Technology of Nickel-based Superalloys Used for Aero-engine. Journal of Mechanical Engineering 55(01):189-215. (in Chinese)

Du Y, Gao B, Zhou H, Ju X, Hao H, Yin S (2013). Health risk assessment of heavy metals in road dusts in urban parks of Beijing, China. Procedia Environmental Sciences 18:299-309. https://doi.org/10.1016/j.proenv.2013.04.039.

Gong X, Chen Z, Luo Z (2014). Spatial distribution, temporal variation, and sources of heavy metal pollution in groundwater of a century-old nonferrous metal mining and smelting area in China. Environmental Monitoring and Assessment 186(12):9101-9116. https://doi.org/10.1007/s10661-014-4069-y.

Gope M, Masto RE, George J, Balachandran S (2018). Tracing source, distribution and health risk of potentially harmful elements (PHEs) in street dust of Durgapur, India. Ecotoxicology and Environmental Safety 154:280-293. https://doi.org/10.1016/j.ecoenv.2018.02.042.

Gope M, Masto RE, George J, Hoque RR, Balachandran S (2017). Bioavailability and health risk of some potentially toxic elements $(\mathrm{Cd}, \mathrm{Cu}, \mathrm{Pb}$ and $\mathrm{Zn})$ in street dust of Asansol, India. Ecotoxicology and Environmental Safety 138:231-241. https://doi.org/10.1016/j.ecoenv.2017.01.008.

Hu B, Liu B, Zhou J, Guo J, Sun Z, Meng W, Guo X, Duan J (2016). Health risk assessment on heavy metals in urban street dust of tianjin based on trapezoidal fuzzy numbers. Human and Ecological Risk Assessment: An International Journal 22(3):678-692. https://doi.org/10.1080/10807039.2015.1104625.

Jiao X, Teng Y, Zhan Y, Wu J, Lin X (2015). Soil heavy metal pollution and risk assessment in shenyang industrial district, northeast china. PLOS ONE 10(5):e0127736. https://doi.org/10.1371/journal.pone.0127736.

Khademi H, Gabarrón M, Abbaspour A, Martínez-Martínez S, Faz A, Acosta JA (2019). Environmental impact assessment of industrial activities on heavy metals distribution in street dust and soil. Chemosphere 217:695-705. https://doi.org/10.1016/j.chemosphere.2018.11.045.

Khanal R, Furumai H, Nakajima F, Yoshimura C (2018). Carcinogenic profile, toxicity and source apportionment of polycyclic aromatic hydrocarbons accumulated from urban road dust in Tokyo, Japan. Ecotoxicology and environmental safety, 165:440-449. https://doi.org/10.1016/j.ecoenv.2018.08.095

Lanzerstorfer C (2018). Heavy metals in the finest size fractions of road-deposited sediments. Environmental Pollution 239:522-531. https://doi.org/10.1016/j.envpol.2018.04.063.

Li H, Chen L, Yu L, Guo Z, Shan C, Lin J, Gu Y, Yang Z, Yang Y, Shao J, Zhu X, Cheng Z (2017). Pollution characteristics and risk assessment of human exposure to oral bioaccessibility of heavy metals via urban street dusts from different functional areas in Chengdu, China. Science of The Total Environment 586:1076-1084. https://doi.org/10.1016/j.scitotenv.2017.02.092.

Li X, Liu L, Wang Y, Luo G, Chen X, Yang X, Hall Myrna, Guo R, Wang H, Cui J, He X (2013). Heavy metal contamination of urban soil in an old industrial city (Shenyang) in Northeast China. Geoderma 192:50-58. https://doi.org/10.1016/j.geoderma.2012.08.011. 
Liang L, An L, Yang L, Zhang L, Zhang G, Guan Y (2016). Polycyclic aromatic hydrocarbons associated with road deposited solid and their ecological risk: implications for road stormwater reuse. Science of the Total Environment 563-564:190-198. https://doi.org/10.1016/j.scitotenv.2016.04.114.

Liu E, Yan T, Birch Gavin, Zhu Y (2014). Pollution and health risk of potentially toxic metals in urban road dust in Nanjing, a mega-city of China. Science of the Total Environment 476-477:522-531. https://doi.org/10.1016/j.scitotenv.2014.01.055.

Liu L, Cui Z, Wang Y, Rui Y, Yang Y, Xiao Y (2018). Contamination features and health risk of heavy metals in suburban vegetable soils, Yanbian, Northeast China. Human \& Ecological Risk Assessment. 1-16. https://doi.org/10.1080/10807039.2018.1450135.

Lu X, Pan H, Wang Y (2017a). Pollution evaluation and source analysis of heavy metal in roadway dust from a resource-typed industrial city in Northwest China. Atmospheric Pollution Research 8(3):587-595. https://doi.org/10.1016/j.apr.2016.12.019.

Lu X, Shi D, Yin N, Pan H, Smith Paris (2017b). Risk assessment of heavy metals in finer than 63- $\mu \mathrm{m}$ dust particles from various functional areas in Xi'an, China. Air Quality, Atmosphere \& Health 10(7):907-915. https://doi.org/10.1007/s11869-017-0480-1.

Lu X, Wang L, L LY, Lei K, Huang L, Kang D (2010). Multivariate statistical analysis of heavy metals in street dust of Baoji, NW China. Journal of Hazardous Materials 173(1-3):744-749. https://doi.org/10.1016/j.jhazmat.2009.09.001.

Maanan M, Saddik M, Maanan M, Chaibi M, Assobhei O, Zourarah B (2015). Environmental and ecological risk assessment of heavy metals in sediments of Nador lagoon, Morocco. Ecological Indicators 48:616-626. https://doi.org/10.1016/j.ecolind.2014.09.034.

Mathur R, Balaram V, Satyanarayanan M, Sawant SS (2016). Assessment of heavy metal contamination of road dusts from industrial areas of Hyderabad, India. Environmental Monitoring \& Assessment 188(9):514. https://doi.org/10.1007/s10661-016-5496-8.

Men C, Liu R, Wang Q, Guo L, Shen Z (2018a). The impact of seasonal varied human activity on characteristics and sources of heavy metals in metropolitan road dusts. Science of the Total Environment 637: 844-854. https://doi.org/10.1016/j.scitotenv.2018.05.059.

Men C, Liu R, Xu F, Wang Q, Guo L, Shen Z (2018b). Pollution characteristics, risk assessment, and source apportionment of heavy metals in road dust in beijing, china. Science of The Total Environment 612:138-147. https://doi.org/10.1016/j.scitotenv.2017.08.123.

Mousavian N A, Mansouri N, Nezhadkurki F (2017). Estimation of heavy metal exposure in workplace and health risk exposure assessment in steel industries in iran. Measurement 102:286-290. https://doi.org/10.1016/j.measurement.2017.02.015.

Ogunkunle C O, Fatoba P O (2014). Contamination and spatial distribution of heavy metals in topsoil surrounding a mega cement factory. Atmospheric Pollution Research 5(2):270-282. https://doi.org/10.5094/APR.2014.033.

Pan H, Lu X, Lei K (2017). A comprehensive analysis of heavy metals in urban road dust of Xi'an, China: Contamination, source apportionment and spatial distribution. Science of the Total Environment 609:1361-1369. https://doi.org/10.1016/j.scitotenv.2017.08.004.

Raja R, Nayak AK, Rao KS, Puree C, Shahid M, Panda BB, Kumar A, Tripathi R, Bhattacharyya P, Baig MJ, Lal B, Mohanty S, Gautam P (2014). Effect of fly ash deposition on photosynthesis, growth and yield of Rice. Bulletin of Environmental Contamination and Toxicology 93:106-112. https://doi.org/ 10.1007/s00128-014-1282-X. 
Salo H, Paturi P, Mkinen J (2016). Moss bag (sphagnum papillosum) magnetic and elemental properties for characterising seasonal and spatial variation in urban pollution. International journal of Environmental Science and Technology 13(6):1515-1524. https://doi.org/10.1007/s13762-0160998-z.

SEPA (State Environmental Protection Administration of China) (1997). Soil Quality-Determination of Copper, Zinc-Flame atomic absorption spectrophotometry. GB/T 17138-1997. Ministry of Environment Protection of the People's Republic of China, Beijing, China. (in Chinese)

Shenyang Statistics Bureau (SSB) (2020). Statistical bulletin of national economic and social development of Shenyang in 2019. http://tjj.shenyang.gov.cn/systjj/tjsj/ndsj/glist.html. Accessed 31 December 2020 (in Chinese).

Shi D, Lu X (2018). Accumulation degree and source apportionment of trace metals in smaller than 63 $\mu \mathrm{m}$ road dust from the areas with different land uses: A case study of Xi'an, China. Science of The Total Environment 636:1211-1218. https://doi.org/10.1016/j.scitotenv.2018.04.385.

Shi X, Chen L, Wang J (2013). Multivariate analysis of heavy metal pollution in street dusts of Xianyang city, NW China. Environmental Earth Sciences 69(6):1973-1979. https://doi.org/10.1007/s12665-012-2032-1.

Soltani N, Keshavarzi B, Moore F, Tavakol T, Reza Lahijanzadeh A, Jaafarzadeh N, Kermani M (2015). Ecological and human health hazards of heavy metals and polycyclic aromatic hydrocarbons (PAHs) in road dust of Isfahan metropolis, Iran. Science of the Total Environment 505:712-723. https://doi.org/10.1016/j.scitotenv.2014.09.097.

Taiwo AM, Awomeso JA, Taiwo OT, Oremodu BD, Akintunde OO, Ojo NO, Elegbede, OO, Olanrewaju $\mathrm{HH}$, Arowolo TA (2017). Assessment of health risks associated with road dusts in major traffic hotspots in Abeokuta Metropolis, Ogun State, Southwestern Nigeria. Stochastic Environmental Research and Risk Assessment 31:431-447. https://doi.org/10.1007/s00477-016-1302-y.

Talbi A, Kerchich Y, Kerbachi R, Boughedaoui M (2017). Assessment of annual air pollution levels with PM 1, PM 2.5, PM 10 and associated heavy metals in Algiers, Algeria. Environmental Pollution 232:252-263. https://doi.org/10.1016/j.envpol.2017.09.041.

Tang Z, Chai M, Cheng J, Jin J, Yang Y, Nie Z, Huang Q, Li Y (2017). Contamination and health risks of heavy metals in street dust from a coal-mining city in eastern China. Ecotoxicology \& Environmental Safety 138:83-91. https://doi.org/10.1016/j.ecoenv.2016.11.003.

Trujillo-González JM, Torres-Mora MA, Keesstra S, Brevik EC, Jiménez-Ballesta R (2016). Heavy metal accumulation related to population density in road dust samples taken from urban sites under different land uses. Science of Total Environmet 553:636-642. https://doi.org/10.1016/j.scitotenv.2016.02.101.

Urrutia-Goyes R, Hernandez N, Carrillo-Gamboa O, Nigam KDP, Ornelas-Soto N (2018). Street dust from a heavily-populated and industrialized city: evaluation of spatial distribution, origins, pollution, ecological risks and human health repercussions. Ecotoxicology and Environmental Safety 159:198-204. https://doi.org/10.1016/j.ecoenv.2018.04.054.

USEPA (US Environmental Protection Agency) (1989). Risk Assessment Guidance for Superfund, Vol.

I: Human Health Evaluation Manual vol EPA/540/1-89/002. Office of Soild Waste and Emergency Response, Washington, DC, USA.

USEPA (US Environmental Protection Agency) (1997). Exposure Factors Handbook. Environmental Protection Agency, Office of Research and Development, Washington, DC, USA.

USEPA (US Environmental Protection Agency) (2001). Supplemental Guidance for Developing Soil 
Screening Levels for Superfund Sites vol OSWER 9355.4-24. Office of Solid Waste and Emergency Response, Washington, DC, USA.

Usmani Z, Kumar V (2017). Characterization, partitioning, and potential ecological risk quantification of trace elements in coal fly ash. Environmental Science \& Pollution Research 24(18):1-20. https://doi.org/10.1007/s11356-017-9171-6.

Verma SK, Masto RE, Gautam S, Choudhury DP, Ram LC, Maiti SK, Maity S (2015). Investigations on PAHs and trace elements in coal and its combustion residues from a power plant. Fuel 162:138147. https://doi.org/10.1016/j.fuel.2015.09. 005.

Wan D, Han Z, Yang J, Yang G, Liu X (2016). Heavy Metal Pollution in Settled Dust Associated with Different Urban Functional Areas in a Heavily Air-Polluted City in North China. International journal of environmental research and public health, 13(11):1119. https://doi.org/10.3390/ijerph13111119

Wang J, Li S, Cui X, Li H, Qian X, Wang C, Sun Y (2016). Bioaccessibility, sources and health risk assessment of trace metals in urban park dust in Nanjing, Southeast China. Ecotoxicology and Environmental Safety 128:161-170. https://doi.org/10.1016/j.ecoenv.2016.02.020.

Wei B, Jiang F, Li X, Mu S (2010). Heavy metal induced ecological risk in the city of Urumqi, NW China. Environmental Monitoring \& Assessment 160(1-4):33-45. https://doi.org/10.1007/s10661-0080655-1.

Wei X, Gao B, Wang P, Zhou H, Lu J (2015). Pollution characteristics and health risk assessment of heavy metals in street dusts from different functional areas in Beijing, China. Ecotoxicology and Environmental Safety 112:186-192. https://doi.org/10.1016/j.ecoenv.2014.11.005.

Yan G, Mao L, Liu S, Mao Y, Ye H, Huang T, Li F, Chen L (2018). Enrichment and sources of trace metals in roadside soils in Shanghai, China: A case study of two urban/rural roads. Science of the Total Environment. s631-632:942-950. https://doi.org/10.1016/j.scitotenv.2018.02.340.

Yang T, Zeng Q, Liu Z, Liu QS (2011). Magnetic properties of the road dusts from two parks in Wuhan city, China: Implications for mapping urban environment. Environmental Monitoring and Assessment 177(1-4):637-648. https://doi.org/10.1007/s10661-010-1662-6.

Yıldırım G, Tokalıoğlu Ş (2016). Heavy metal speciation in various grain sizes of industrially contaminated street dust using multivariate statistical analysis. Ecotoxicology and environmental safety, 124:369-376. https://doi.org/10.1016/j.ecoenv.2015.11.006. 


\section{Supplementary Files}

This is a list of supplementary files associated with this preprint. Click to download.

- Supportinginformation.docx 